\title{
Smoking as a Crucial Independent Determinant of Stroke
}

\author{
Seana L. Paul, Amanda G. Thrift, Geoffrey A. Donnan \\ National Stroke Research Institute, Austin Health, Heidelberg West, Victoria 3081, Australia
}

\begin{abstract}
Background: Although smoking is known to be powerful risk factor for other vascular diseases, such as cardiac and peripheral vascular disease, only relatively recently has evidence for the role of smoking in the development of stroke been established. The reasons for this advance lie in the acknowledgement that stroke is a heterogeneous disease, in which its subtypes are associated with different risk factors. Furthermore, improvements in the stringency of epidemiological studies and the greater use of CT scanning have enabled the role of smoking in the development of stroke to be elucidated. Summary of review: This is a qualitative examination of high quality epidemiological studies in which the role of smoking and passive smoking, as a risk factor for cerebral infarction, intracerebral haemorrhage and subarachnoid haemorrhage, is examined. In addition, the pathological mechanisms by which smoking or passive smoking may contribute to the development of stroke are reviewed. Conclusion: Smoking is a crucial independent determinant of cerebral infarction and subarachnoid haemorrhage, however its role in intracerebral haemorrhage is unclear. Although studies are limited, there is evidence that exposure to passive smoking may also increase the risk of stroke. Smoking appears to be involved in the pathogenesis of stroke via direct injury to the vasculature and also by altering haemodynamic factors within the circulation. Importantly, smoking is modifiable risk factor for stroke. Therefore, the encouragement of smoking cessation may result in a substantial reduction in the incidence of this devastating disease.
\end{abstract}

KEYwORDS: Smoking, Epidemiology, Review, Cerebral Infarction, Subarachnoid Haemorrhage, Intracerebral Haemorrhage

\section{INTRODUCTION}

Although smoking is an established and potent risk factor for other vascular diseases, such as cardiac and peripheral vascular disease [1,2], the evidence for its status as a risk factor for stroke has been gained only in the last 20 years [3-33]. That it took so long to establish smoking as a risk factor for stroke might be largely attributed to three main factors. First, epidemiological studies have become more stringent over the past two decades, with methodology being refined to reduce bias associated with ascertainment of both cases and controls. Second, the purpose of many of the earlier studies was not to determine whether smoking was a risk factor for stroke, but was mainly a result of post-hoc analyses. Consequently the methodology was more likely to include means of inadvertently choosing inappropriate samples for comparison. Finally, stroke is a heterogeneous condition, and it is only since the introduction of CT scanning that an accurate diagnosis of stroke and its subtypes has been possible. Previously, it is possible the epidemiological studies included other non-stroke conditions that may have been of nonvascular origin. Moreover, it is also possible that the differing aetiologies of cerebral ischaemia and cerebral haemorrhage may have resulted in a diminution of risk when these stroke subtypes were combined into an overall "stroke"

Correspondence: Prof. G.A. Donnan, National Stroke Research Institute, Neurosciences Building, Austin Health - Repatriation Campus, 300 Waterdale Road, West Heidelberg, Victoria 3081, Australia.

Email: thrift@unimelb.edu.au

Fax: + (61-3) 9496-2650 
group. Because of this possibility, we will discuss the association between smoking and its subtypes (cerebral infarction, subarachnoid and cerebral haemorrhage) separately. In addition, the studies that will be discussed are those that have a high rate of CT for accurate classification of these subtypes. This review is intended as a qualitative overview of the key literature regarding the association between smoking and stroke, and is not a detailed meta-analysis.

\section{CEREBRAL INFARCTION}

Cerebral infarction is the most common subtype of stroke, accounting for more than $70 \%$ of all strokes [34]. Over the past few decades cigarette smoking has been established as a major risk factor for the development of cerebral infarction [11-13,17-19,21,23,25,28, $35]$. In a meta-analysis of 22 studies of the association between cigarette smoking and stroke prior to 1988 , Shinton and Beevers found that the relative risk for cerebral infarction associated with smoking was 1.92 (95\% CI, 1.71-2.16) [28].

The relationship between smoking and cerebral infarction has been confirmed in more recent casecontrol studies from the U.S., Australia, U.K., Scandinavia, and Russia (Table 1) [10-13,17,20,23,25,35]. In a study among more than 400 patients in Australia, Donnan and colleagues found that the risk of cerebral infarction due to smoking was substantially higher than in the previous meta-analysis [10]. In this study, which included adjustments for the potentially confounding effects of hypertension, high cholesterol, previous myocardial infarction, alcohol consumption and oral contraceptive use, the relative risk of cerebral ischaemia associated with current smoking was 3.6 (95\% CI, 2.5-5.9). Similar results were found by Gorelick and colleagues in the United States and by Gill and colleagues in the United Kingdom [12,13]. In the latter case-control study, which included 368 cases of CI and 573 controls, the adjusted relative risk of CI with smoking was 3.19 (95\% CI, 1.8-5.5) among men and 2.3 (95\% CI, 1.24.2) among women after adjustment for confounding variables such as age, social class, hypertension and alcohol consumption.

Similar results have been obtained in cohort studies in the United States and Taiwan [18,19,21,36]. In the U.S. Physicians' Health Study, Kurth and colleagues found that current smoking was associated with a twofold increase in the risk of ischaemic stroke (RR 2.11, 95\% CI, 1.72-2.60) [19]. Those smoking <20 cigarettes/day were found to have a 1.6-fold increase in the risk of ischaemic stroke (RR, 1.56, 95\% CI, 1.03$2.37)$ and this increased to 2.25 (95\% CI, 1.80-2.81) among those smoking $\geq 20$ cigarettes/day when compared to never smokers. These relative risks were adjusted for the confounding effects of age, alcohol consumption, exercise and parental history of myocardial infarction less than 60 years of age. In a similar study conducted in a large cohort of female nurses, Kawachi and colleagues found that current smokers were at a significantly greater risk of CI (RR 2.53, 95\% CI, 1.913.35) [18]. Importantly, these investigators found a dose-response relationship between the level of smoking and cerebral infarction $(\mathrm{p}=0.03)$. Those smoking 1-14 cigarettes/day had an adjusted RR of 1.8 (95\% CI, 1.04-3.23), with the risk increasing to 3.97 (95\% CI, 2.09-7.53) for women smoking $\geq 35$ cigarettes/day., Together, these studies provide evidence that smoking increases the risk of cerebral infarction in both men and women, with the risk being greater in those who smoke more.

The use of pack-years by investigators to determine the dose of lifetime exposure to cigarettes was used in some studies $[13,23]$. This is a combination of both the number of cigarettes smoked per day and the duration of smoking (where a pack is defined as 20 cigarettes per day and this is multiplied by the number of years to calculate pack-years). Love and colleagues reported that the risk of cerebral infarction increased by $4 \%$ per pack-year smoked. In support of these findings, Gorelick and colleagues found that individuals who had been smoking for 1-33 pack-years had an odds ratio (OR) for cerebral infarction of $2.48(95 \% \mathrm{CI}, 1.43-$ 4.29). This increased to an OR of 5.60 (95\% CI, 3.179.88 ) in those smoking more than 33 pack-years. This provides evidence that there is an increased stroke risk with increased pack-years of smoking.

The difference in the definition used for exposure is an important issue. Measuring pack-years provides information on both the quantity of cigarettes smoked and the duration of this level of smoking. Thus it could be that either or both of these factors contribute to the increased stroke risk. It would be useful to determine whether one pack per day for 20 years produced a stroke risk similar to that of two packs per day for 10 years (with both equating to 20 pack-years). However, this type of information relies heavily on participant recall. Such accurate recall may be challenging, especially for individuals with cognitive deficits following stroke. Partly because of the difficulties outlined, it remains to be established whether it is the quantity or 
Table 1: Smoking and the risk of cerebral infarction, summary of studies

\begin{tabular}{|c|c|c|c|c|c|c|c|}
\hline & $\begin{array}{l}\text { No. CI } \\
\text { cases } \\
\text { (No. in } \\
\text { cohort) }\end{array}$ & $\begin{array}{c}\text { No. } \\
\text { Controls }\end{array}$ & $\begin{array}{l}\text { Smoking } \\
\text { Status }\end{array}$ & $\begin{array}{l}\mathbf{R R} / \\
\text { OR }\end{array}$ & $95 \%$ CI & Adjustments $\dagger$ & Matching \\
\hline $\begin{array}{l}\text { Case-Control } \\
\text { Studies }\end{array}$ & & & & & & & \\
\hline $\begin{array}{l}\text { Donnan et al. [10] } \\
\text { Melbourne, Aus- } \\
\text { tralia, } 1989\end{array}$ & 422 & 422 & $\begin{array}{l}\text { Never smoker } \\
\text { Ex smoker } \\
\text { Current smoker }\end{array}$ & $\begin{array}{l}1.0 \\
2.0 \\
3.6\end{array}$ & $\begin{array}{l}1.3-3.2 \\
2.2-5.9\end{array}$ & $\begin{array}{l}\text { Hypertension, High } \\
\text { cholesterol, MI, alcohol } \\
\text { consumption, oral } \\
\text { contraceptive use. }\end{array}$ & $\begin{array}{l}\text { Age, sex, } \\
\text { neighbourhood }\end{array}$ \\
\hline $\begin{array}{l}\text { Gorelick et al [13] } \\
\text { Illinois, U.S. } 1989\end{array}$ & 205 & 410 & $\begin{array}{l}0 \text { (pack-years) } \\
1-32 \text { (pack years) } \\
\geq 33 \text { (pack-years) }\end{array}$ & $\begin{array}{l}1.00 \\
2.48 \\
5.60\end{array}$ & $\begin{array}{l}1.43-4.29 \\
3.17-9.88\end{array}$ & $\begin{array}{l}\text { Hypertension, and } \\
\text { alcohol consumption. }\end{array}$ & $\begin{array}{l}\text { Age, race, sex } \\
\text { and method of } \\
\text { hospital payment }\end{array}$ \\
\hline $\begin{array}{l}\text { Gill et al [12] } \\
\text { British Midlands, } \\
\text { U.K } 1989\end{array}$ & 368 & 573 & $\begin{array}{l}\text { Nonsmokers } \\
\text { Current (Male) } \\
\text { Current (Female) }\end{array}$ & $\begin{array}{l}1.00 \\
3.19 \\
2.26\end{array}$ & $\begin{array}{l}1.8-5.5 \\
1.2-4.2\end{array}$ & $\begin{array}{l}\text { Age, race, social class, } \\
\text { alcohol consumption } \\
\text { and treatment of hyper- } \\
\text { tension. }\end{array}$ & \\
\hline $\begin{array}{l}\text { Love et al. [23] } \\
\text { Iowa, U.S. } \\
1990\end{array}$ & $\begin{array}{c}181 \\
15-45 \\
\text { years }\end{array}$ & 307 & $\begin{array}{l}\text { Current Smoker } \\
\text { Past Smoker } \\
\text { Per cigarette/day } \\
\text { Per pack-year }\end{array}$ & $\begin{array}{l}1.43 \\
0.64 \\
1.01 \\
1.04\end{array}$ & $\begin{array}{l}0.98-2.11 \\
0.25-1.69 \\
1.00-1.03 \\
1.02-1.05\end{array}$ & No adjustments. & $\begin{array}{l}\text { Age, gender, } \\
\text { hospital admis- } \\
\text { sion date, and } \\
\text { county of resi- } \\
\text { dence. }\end{array}$ \\
\hline $\begin{array}{l}\text { Ellekjær et al [35] } \\
\text { North Trøndelag } \\
\text { County, Norway } \\
1992 .\end{array}$ & 163 & 567 & $\begin{array}{l}\text { Never smoker } \\
\text { Current Smoking } \\
\text { Prior Smoking }\end{array}$ & $\begin{array}{l}1.00 \\
1.72 \\
2.54\end{array}$ & $\begin{array}{l}0.85-3.51 \\
1.22-5.29\end{array}$ & $\begin{array}{l}\text { Diabetes, previous } \\
\text { myocardial infarction, } \\
\text { previous stroke, and } \\
\text { systolic blood pressure. }\end{array}$ & $\begin{array}{l}\text { Sex, year of } \\
\text { birth, and local } \\
\text { government } \\
\text { area. }\end{array}$ \\
\hline $\begin{array}{l}\text { Lidegaard et al. } \\
\text { [20] } \\
\text { Denmark, } 1993\end{array}$ & $\begin{array}{c}320 \\
\text { females } \\
15-44 \\
\text { years }\end{array}$ & 1198 & $\begin{array}{l}\text { Never smoker } \\
\text { Former smoker } \\
\text { Smoking } \leq 10 / \text { day } \\
\text { Smoking }>10 / \text { day }\end{array}$ & $\begin{array}{l}1.0 \\
0.6 \\
1.6 \\
1.5\end{array}$ & $\begin{array}{l}0.4-0.9 \\
1.1-2.4 \\
1.1-2.0\end{array}$ & $\begin{array}{l}\text { Age, use of oral } \\
\text { contraceptives, years } \\
\text { of schooling }\end{array}$ & \\
\hline $\begin{array}{l}\text { Jamrozik et al. } \\
\text { [17] } \\
\text { Perth, Australia, } \\
1994\end{array}$ & 360 & 518 & $\begin{array}{l}\text { Never Smoker } \\
\text { Ex-smoker } \\
\text { Current (1-20/day) } \\
\text { Current ( } \geq 21 / \text { day) }\end{array}$ & $\begin{array}{l}1.00 \\
0.49 \\
1.45 \\
4.92\end{array}$ & $\begin{array}{l}0.31-0.81 \\
0.81-2.68 \\
1.90-12.7\end{array}$ & $\begin{array}{l}\text { Alcohol, hypertension, } \\
\text { diabetes, previous stroke } \\
\text { or TIA, previous MI, } \\
\text { adding salt to food, fish } \\
\text { consumption }>2 \text { per } \\
\text { month. }\end{array}$ & Sex and age. \\
\hline $\begin{array}{l}\text { Petitti et al [25] } \\
\text { California, US } \\
1996\end{array}$ & $\begin{array}{c}144 \\
\text { females } \\
15-44 \\
\text { years }\end{array}$ & 774 & $\begin{array}{l}\text { Never } \\
\text { Past } \\
\text { Occasional } \\
\text { Current }\end{array}$ & $\begin{array}{l}1.00 \\
0.94 \\
1.38 \\
2.66\end{array}$ & $\begin{array}{l}0.55-1.59 \\
0.42-4.56 \\
1.65-4.30\end{array}$ & No adjustments. & $\begin{array}{l}\text { Year of birth, } \\
\text { location of } \\
\text { facility. }\end{array}$ \\
\hline $\begin{array}{l}\text { Feigin et al [11] } \\
\text { Novosibirsk, } \\
\text { Russia } 1998\end{array}$ & 237 & 237 & $\begin{array}{l}\text { Non smoker } \\
\text { Current }\end{array}$ & $\begin{array}{l}1.00 \\
2.20\end{array}$ & $0.99-4.78$ & $\begin{array}{l}\text { Hypertension, LVH, } \\
\text { IHD, mitral valve } \\
\text { disease, and BMI. }\end{array}$ & Age and sex. \\
\hline
\end{tabular}


Table 1, Continued

\begin{tabular}{|c|c|c|c|c|c|c|c|}
\hline & $\begin{array}{l}\text { No. CI } \\
\text { cases } \\
\text { (No. in } \\
\text { cohort) }\end{array}$ & $\begin{array}{c}\text { No. } \\
\text { Controls }\end{array}$ & Smoking Status & $\begin{array}{c}\mathbf{R R} / \\
\mathbf{O R}\end{array}$ & $95 \% \mathrm{CI}$ & Adjustments $\dagger$ & Matching \\
\hline \multicolumn{8}{|l|}{ Cohort Studies } \\
\hline $\begin{array}{l}\text { Kawachi et al } \\
\text { [18] } \\
\text { Nurses' Health } \\
\text { Study, U.S., } \\
1993 .\end{array}$ & $\begin{array}{c}275 \\
(117006 \\
\text { females })\end{array}$ & $\begin{array}{l}\text { Rest of } \\
\text { stroke free } \\
\text { cohort }\end{array}$ & $\begin{array}{l}\text { Never Smokers } \\
\text { Ex-smokers } \\
\text { Current Smokers } \\
\quad 1-14 / \text { day } \\
\quad 15-24 / \text { day } \\
25-34 / \text { day } \\
\geq 35 / \text { day }\end{array}$ & $\begin{array}{l}1.00 \\
1.27 \\
2.53 \\
1.83 \\
3.57 \\
2.73 \\
3.97\end{array}$ & $\begin{array}{l}0.85-1.89 \\
1.91-3.35 \\
1.04-3.23 \\
2.36-5.42 \\
1.49-5.03 \\
2.09-7.53\end{array}$ & $\begin{array}{l}\text { Age, hypertension, } \\
\text { diabetes, BMI, high } \\
\text { cholesterol, oral contra- } \\
\text { ceptive use, HRT, age of } \\
\text { smoking commencement, } \\
\text { and follow-up period. }\end{array}$ & \\
\hline $\begin{array}{l}\text { Benfante et al. } \\
\text { [36] } \\
\text { Hawaii, } 1994\end{array}$ & 226 & $\begin{array}{l}5567 \text { (rest } \\
\text { of cohort) }\end{array}$ & $\begin{array}{l}\text { Non smokers } \\
\text { Current Smokers }\end{array}$ & $\begin{array}{l}1.0 \\
2.30\end{array}$ & $1.8-3.0$ & & \\
\hline $\begin{array}{l}\text { Lee et al. [21] } \\
\text { Taiwan, } 1995\end{array}$ & $\begin{array}{c}115 \\
(2600,> \\
65 \text { years })\end{array}$ & $\begin{array}{l}\text { Rest of } \\
\text { Cohort }\end{array}$ & $\begin{array}{l}\text { Never smokers } \\
\text { Current Heavy ( }> \\
20 \text { per day) }\end{array}$ & $\begin{array}{l}1.00 \\
1.72\end{array}$ & $1.00-2.96$ & $\begin{array}{l}\text { Age, sex, hyperten- } \\
\text { sion, diabetes, and } \\
\text { alcohol. }\end{array}$ & $\begin{array}{l}\text { Prevalence } \\
\text { Study }\end{array}$ \\
\hline $\begin{array}{l}\text { Kurth et al. [19] } \\
\text { Physicians' } \\
\text { Health Study, } \\
\text { US, } 2003\end{array}$ & $\begin{array}{r}913 \\
(22022 \\
\text { Males })\end{array}$ & $\begin{array}{l}\text { Rest of } \\
\text { cohort }\end{array}$ & $\begin{array}{l}\text { Never Smokers } \\
\text { Ex-Smokers } \\
\text { Current Smokers } \\
\quad<20 / \text { day } \\
\quad \geq 20 / \text { day }\end{array}$ & $\begin{array}{l}1.00 \\
0.99 \\
1.56 \\
2.25\end{array}$ & $\begin{array}{l}0.86-1.14 \\
1.03-2.37 \\
1.80-2.81\end{array}$ & $\begin{array}{l}\text { Age, alcohol, exercise, } \\
\text { parental history of MI } \\
<60 \mathrm{yr} \text {, and randomised } \\
\text { treatment group. }\end{array}$ & \\
\hline
\end{tabular}

CI, cerebral infarction; RR, relative risk; OR, odds ratio; 95\% CI, Confidence Interval; †adjustments refer to adjustments made in multivariate analyses. MI, myocardial infarction; TIA, transient ischaemic attack; LVH, left ventricular hypertrophy; IHD, ischaemic heart disease; BMI, body mass index; HRT, hormone replacement therapy.

the duration of smoking that results in the increased risk of cerebral infarction.

The effect of cessation of smoking on the subsequent development of cerebral infarction is important in determining a causal relationship between this disease and smoking. In men, Kurth and colleages found that past smokers had a risk of cerebral infarction comparable to that of never smokers (RR 0.99, 95\% CI, 0.861.14) [19]. Kawachi and colleagues provided further evidence for a return to never smoking risk levels among those who cease smoking [18]. They examined the number of years since quitting smoking $(<2$ years, 2-4 years, 5-9 years, 10-14 year and $>15$ years) on the risk of cerebral infarction in women. Current smokers were used as reference for the reduction in risk. At two years after quitting, the risk of stroke was reduced by $46 \%$ (RR $0.54,95 \% \mathrm{CI}, 0.26-1.55$ ). This equated to $80 \%$ of the benefit of smoking cessation and demonstrating the immediate benefits of smoking cessation.
Furthermore, the relative risk of ischaemic stroke among former smokers returned to the level of never smokers during the interval between 2 and 4 years following smoking cessation.

Similar results have been reported from casecontrol studies. In studies conducted in the U.S. $[23,25]$, ex-smokers were found to have a risk of cerebral infarction similar to that of never smokers (RR 0.94, 95\% CI, 0.55-1.59) and (0.64 95\% CI, 0.25-1.69) for each of these studies respectively. Although it is possible that ex-smokers may reduce their risk of cerebral infarction simply by ceasing smoking, other lifestyle changes made at the time of smoking cessation may contribute to a reduction in cerebral infarction risk.

\section{SUBARACHNOID HAEMORRHAGE}

Subarachnoid haemorrhage (SAH) accounts for only about $2-9 \%$ of strokes [37], but is associated with mortality of between $39 \%$ and $58 \%$ at one year and 
Table 2: Smoking and the risk of subarachnoid haemorrhage: summary of studies

\begin{tabular}{|c|c|c|c|c|c|c|c|}
\hline & $\begin{array}{l}\text { No. } \\
\text { SAH } \\
\text { cases } \\
\text { (No. in } \\
\text { cohort) }\end{array}$ & $\begin{array}{l}\text { No. of } \\
\text { con- } \\
\text { trols }\end{array}$ & $\begin{array}{l}\text { Smoking } \\
\text { Status }\end{array}$ & $\begin{array}{l}\mathbf{R R} / \\
\text { OR }\end{array}$ & $95 \% \mathrm{CI}$ & Adjustments $\dagger$ & Matching \\
\hline \multicolumn{8}{|c|}{ Case-Control Studies } \\
\hline $\begin{array}{l}\text { Gill et al. [12] } \\
\text { British Midlands, } \\
\text { UK, } 1989\end{array}$ & 208 & 573 & $\begin{array}{l}\text { Nonsmoker } \\
\text { Current (Male) } \\
\text { Current (Female) }\end{array}$ & $\begin{array}{l}1.00 \\
4.52 \\
2.52\end{array}$ & $\begin{array}{l}2.4-8.4 \\
1.4-4.5\end{array}$ & $\begin{array}{l}\text { Age, race, social class, } \\
\text { alcohol consumption and } \\
\text { treatment for hyperten- } \\
\text { sion }\end{array}$ & \\
\hline $\begin{array}{l}\text { Quereshi et al. } \\
{[26]} \\
\text { Maryland US, } \\
2001\end{array}$ & 323 & 969 & $\begin{array}{l}\text { Never } \\
\text { Current Smoker } \\
\text { Previous Smoker }\end{array}$ & $\begin{array}{l}1.0 \\
5.2 \\
4.5\end{array}$ & $\begin{array}{l}3.6-7.5 \\
3.1-6.5\end{array}$ & $\begin{array}{l}\text { Hypertension, diabetes, } \\
\text { alcohol consumption. }\end{array}$ & $\begin{array}{l}\text { Age, } \\
\text { sex, and } \\
\text { ethnicity. }\end{array}$ \\
\hline $\begin{array}{l}\text { Isaksen et al. } \\
{[16]} \\
\text { Tromsø County, } \\
\text { Norway, } 2002\end{array}$ & 26 & 104 & $\begin{array}{l}\text { Never } \\
\text { Former } \\
\text { Current }\end{array}$ & $\begin{array}{l}1.00 \\
2.13 \\
4.55\end{array}$ & $\begin{array}{c}1.04-4.39 \\
1.08-19.30\end{array}$ & $\begin{array}{l}\text { Systolic and diastolic } \\
\text { blood pressure, serum } \\
\text { cholesterol, serum HDL, } \\
\text { BMI, coffee consump- } \\
\text { tion. }\end{array}$ & Age and sex. \\
\hline \multicolumn{8}{|l|}{ Cohort Studies } \\
\hline $\begin{array}{l}\text { Kawachi et al. } \\
{[18]} \\
\text { Nurses' Health } \\
\text { Study, U.S. } 1993\end{array}$ & $\begin{array}{c}108 \\
(117006 \\
\text { females })\end{array}$ & $\begin{array}{l}\text { Rest of } \\
\text { Cohort }\end{array}$ & $\begin{array}{l}\text { Never Smokers } \\
\text { Past Smokers } \\
\text { Current Smokers } \\
\text { 1-14/day } \\
\text { 15-24/day } \\
25-34 / \text { day } \\
\geq 35 / \text { day }\end{array}$ & $\begin{array}{l}1.00 \\
2.26 \\
4.85 \\
4.28 \\
4.02 \\
7.95 \\
10.22\end{array}$ & $\begin{array}{c}1.16-4.42 \\
2.90-8.11 \\
1.88-9.77 \\
1.90-8.54 \\
3.50-18.07 \\
4.03-25.94\end{array}$ & $\begin{array}{l}\text { Age, hypertension, } \\
\text { diabetes, BMI, high } \\
\text { cholesterol, oral contra- } \\
\text { ceptive use, HRT, age of } \\
\text { smoking commencement, } \\
\text { and follow-up period. }\end{array}$ & \\
\hline $\begin{array}{l}\text { Kurth et al. [19] } \\
\text { U.S. Physicians' } \\
\text { Health Study } \\
2003\end{array}$ & $\begin{array}{c}31 \\
(22022 \\
\text { males })\end{array}$ & $\begin{array}{l}\text { Rest of } \\
\text { Cohort }\end{array}$ & $\begin{array}{l}\text { Never Smokers } \\
\text { Ex-Smokers } \\
\text { Current }(<20 / \text { day }) \\
\text { Current }(\geq 20 / \text { day }\end{array}$ & $\begin{array}{l}1.00 \\
0.79 \\
1.75 \\
3.22\end{array}$ & $\begin{array}{c}0.37-1.68 \\
0.24-13.09 \\
1.26-8.18\end{array}$ & $\begin{array}{l}\text { Age, sex, and randomised } \\
\text { treatment group }\end{array}$ & \\
\hline
\end{tabular}

SAH, subarachnoid haemorrhage; RR, relative risk; OR, odds ratio; CI, 95\% Confidence Interval; †adjustments, refers to adjustments made for either univariate or multivariate analysis. HDL, high density lipoprotein; BMI, body mass index; HRT, hormone replacement therapy.

significant morbidity [34,38]. This form of stroke tends to occur at younger ages than other forms of stroke [34]. The contribution of cigarette smoking to this devastating disease has been reported by numerous investigators $[6,12,16,18,19,26,28]$. In a meta-analysis of 10 studies of the association between smoking and SAH, the relative risk of SAH among current smokers was 2.93 (95\% CI, 2.48-3.46) [28]. More recently, Kurth and colleagues found that among current smokers the age-adjusted RR for SAH was 3.61 (95\% CI 1.54-8.50; Table 2) [19]. This study involved more than 22,000 male physicians and included 31 cases of SAH [16]. The work of Qureshi and colleagues, which included 323 patients with $\mathrm{SAH}$, adds further support for these findings [26]. On examination of the medical records of those with SAH admitted to John Hopkins Medical Center between 1990 and 1997, an analysis of risk factors was performed using community-based controls matched for age, sex and ethnicity. More patients with SAH $(46 \%)$ were smokers than controls $(29 \%)$, providing an adjusted odds ratio (OR) of 5.2 (95\% CI, 3.6-7.5) for current smokers. 
In a cohort study Kawachi and colleagues found an adjusted relative risk of SAH of $4.85(95 \%$ CI, 2.90 8.11) among current women smokers [18]. Importantly, these investigators also found that those smoking 1-14 cigarettes/day had an adjusted relative risk (RR) of SAH of 4.28 (95\% CI, 1.88-9.77), which increased to 10.22 (95\% CI, 4.03-25.94) in those smoking $\geq 35$ cigarettes/day. They further reported a dose-response relationship between the daily number of cigarettes smoked and SAH $(\mathrm{p}<0.0004)$. This provides evidence for a causal association between smoking and SAH.

The RR of SAH among former smokers is consistently less than that among current smokers $[16,18,19$, 26]. In the Nurses' Health Study, women who ceased smoking were at less risk of SAH than those who continued to smoke, with RRs of 2.01 (95\% CI, 1.12-3.61) and 4.96 (95\% CI 3.13-7.87) respectively [18]. The investigators also reported that the RR of SAH among former smokers returned to the level of never smokers during the interval between 5 and 9 years following smoking cessation.

These studies demonstrate that smoking is a major independent risk factor for SAH. Importantly, this association is strengthened by the presence of a doseresponse relationship. Of note is that ex-smokers are found to be at a higher risk of SAH than never smokers for many years after smoking cessation, but it appears that within 10 years their risk will return to that of a never smoker [18].

\section{INTRACEREBRAL HAEMORRHAGE}

In a meta-analysis of published studies of smoking and intracerebral haemorrhage (ICH), the pooled relative risk of $\mathrm{ICH}$ associated with smoking was 0.74 (95\% CI, 0.56-0.98) [28]. However, the authors acknowledged that this result was heavily influenced by a single study conducted in neurological hospitals. There have been conflicting reports of the role of smoking in the development of ICH. Some investigators have reported that heavy smoking is associated with ICH $[17,19]$, while others have reported no association between smoking and ICH (Table 3) [12,24,39].

The most recent published data on smoking and intracerebral haemorrhage comes from the Physicians' Health Study, which included 108 cases of ICH [19]. The investigators found that the RR for ICH among current smokers was 1.98 (95\% CI 1.07-3.65) when compared to never smokers. This RR was adjusted for age, alcohol consumption, exercise, parental history of myocardial infarction under 60 years and randomised antioxidant treatment. A non-significant dose-response trend was noted with those smoking $<20$ cigarettes/day having a 1.6-fold increase (RR 1.6, 95\% CI, .50-5.07) in the risk of intracerebral haemorrhage, with the risk increasing to a 2.1-fold increase (RR 2.06, 95\% CI, 1.08-3.96) in those smoking $\geq 20$ cigarettes/day.

Another study that somewhat supports the findings of Kurth and colleagues involved a prospective study of haemorrhagic stroke patients in the US [40]. Although the investigators found smoking was not an independent risk factor for haemorrhagic strokes overall (OR 1.3, 95\% CI, 0.8-2.0), this finding was limited by those with non-lobar haemorrhage [40]. In contrast the association between smoking and lobar haemorrhages was more than twofold (OR 2.4, 95\% CI, 1.1-5.2).

In contrast to the previously mentioned findings, numerous investigators have found no association between smoking and ICH. In a large sample of patients with ICH (331) and using case-control methodology, Thrift and colleagues found no increased risk of intracerebral haemorrhage associated with smoking (adjusted OR, 1.07, 95\% CI, 0.63-1.81) [39]. Importantly, the cases and controls in this study were matched for age ( \pm 5 years), sex, and neighborhood of residence (the latter allowing some degree of matching for socioeconomic status). In addition, the potentially confounding effects of hypertension, cholesterol, body mass index, previous cardiovascular disease, exercise, education level, diabetes, and alcohol consumption were adjusted for in the analyses.

The results of 13 studies, in which the contribution of smoking in the risk of ICH was investigated, were included in a recent meta-analysis [41]. The authors found that the risk of ICH with smoking was 1.31 (95\% CI, 1.09-1.50). However, this study was limited by the fact that no adjustments could be made by potentially confounding factors, and so the independence of smoking as a risk factor could not be established. Therefore, the contribution of smoking to the risk of ICH is still in doubt.

\section{PASSIVE SMOKING AND THE RISK OF STROKE}

Beyond the damage that active smoking may cause an individual are the adverse effects that inhaling environmental tobacco smoke (ETS) from the sidestream smoke of a burning cigarette may cause others. This smoke contains high concentrations of $\mathrm{CO}$, nicotine and carcinogens [42]. In some cases these combustion products are of a higher concentration in sidestream 
Table 3: Smoking and the risk of intracerebral haemorrhage: summary of studies

\begin{tabular}{|c|c|c|c|c|c|c|c|}
\hline & $\begin{array}{l}\text { No. } \\
\text { ICH } \\
\text { cases } \\
\text { (No. in } \\
\text { cohort) } \\
\end{array}$ & $\begin{array}{c}\text { No. } \\
\text { controls }\end{array}$ & Smoking Status & RR/OR & $95 \% \mathrm{CI}$ & Adjustments $\dagger$ & Matching \\
\hline \multicolumn{8}{|l|}{$\begin{array}{l}\text { Case-Control } \\
\text { Studies }\end{array}$} \\
\hline $\begin{array}{l}\text { Gill et al. [12] } \\
\text { British Midlands, } \\
\text { UK, } 1989\end{array}$ & 104 & 573 & $\begin{array}{l}\text { Non Smokers } \\
\text { Current (Male) } \\
\text { Current (Female) }\end{array}$ & $\begin{array}{l}1.00 \\
1.82 \\
1.30\end{array}$ & $\begin{array}{l}0.9-3.7 \\
0.5-3.4\end{array}$ & $\begin{array}{l}\text { Age, race, social class, } \\
\text { alcohol consumption, and } \\
\text { treatment of hypertension. }\end{array}$ & \\
\hline $\begin{array}{l}\text { Monforte et al. } \\
{[24]} \\
\text { Barcelona, Spain, } \\
1990\end{array}$ & 24 & 48 & $\begin{array}{l}\text { Non-smokers } \\
\text { Current smokers }\end{array}$ & $\begin{array}{l}1.00 \\
1.52\end{array}$ & $0.41-5.57$ & No adjustments. & Age and sex. \\
\hline $\begin{array}{l}\text { Jamrozik et al. } \\
\text { [17] } \\
\text { Perth, Australia, } \\
1994\end{array}$ & 59 & 279 & $\begin{array}{l}\text { Never Smoker } \\
\text { Ex-smoker } \\
\text { Current (1-20/day) } \\
\text { Current ( } \geq 21 / \text { day })\end{array}$ & $\begin{array}{l}1.00 \\
1.11 \\
3.17 \\
9.84\end{array}$ & $\begin{array}{l}0.43-2.85 \\
0.92-11.0 \\
2.09-46.4\end{array}$ & $\begin{array}{l}\text { Alcohol consumption, } \\
\text { history of hypertension, } \\
\text { diabetes, previous stroke } \\
\text { or TIA, previous MI, add- } \\
\text { ing salt to food, fish con- } \\
\text { sumption > } 2 \text { per month. }\end{array}$ & Sex and age. \\
\hline $\begin{array}{l}\text { Thrift et al.[39] } \\
\text { Melbourne, Aus- } \\
\text { tralia, } 1999\end{array}$ & 331 & 331 & $\begin{array}{l}\text { Never } \\
\text { Smokers } \\
\text { Ever Smokers } \\
\text { Current Smoker } \\
\text { Previous Smoker }\end{array}$ & $\begin{array}{l}1.00 \\
0.96 \\
1.07 \\
0.89\end{array}$ & $\begin{array}{l}0.63-1.45 \\
0.63-1.81 \\
0.56-1.42\end{array}$ & $\begin{array}{l}\text { Hypertension, cholesterol, } \\
\text { BMI, previous cardiovas- } \\
\text { cular disease, exercise, } \\
\text { education level, diabetes, } \\
\text { and alcohol. }\end{array}$ & $\begin{array}{l}\text { Age, sex, and } \\
\text { neighbourhood. }\end{array}$ \\
\hline $\begin{array}{l}\text { Woo et al. [40] } \\
\text { Cincinatti, US, } \\
2002\end{array}$ & $\begin{array}{l}188 \text { sur- } \\
\text { vivors }\end{array}$ & 368 & $\begin{array}{l}\text { Non-smokers } \\
\text { Current Smokers } \\
\text { Current Smokers } \\
\text { Current Smokers }\end{array}$ & $\begin{array}{l}1.0 \\
1.3 \\
2.4 \\
0.9\end{array}$ & $\begin{array}{l}0.8-2.0 \\
1.1-5.2 \\
0.5-1.6\end{array}$ & $\begin{array}{l}\text { No adjustments } \\
\text { All ICH } \\
\text { Lobar ICH } \\
\text { Non-Lobar ICH }\end{array}$ & \\
\hline \multicolumn{8}{|l|}{ Cohort Studies } \\
\hline $\begin{array}{l}\text { Kawachi et al. } \\
{[18]} \\
\text { Nurses' Health } \\
\text { Study, US, } 1993\end{array}$ & $\begin{array}{c}53 \\
(117006 \\
\text { Females })\end{array}$ & $\begin{array}{l}\text { Rest of } \\
\text { Cohort }\end{array}$ & $\begin{array}{l}\text { Never Smokers } \\
\text { Past Smokers } \\
\text { Current Smokers } \\
\text { 1-14/day } \\
\text { 15-24/day } \\
\geq 25 / \text { day }\end{array}$ & $\begin{array}{l}1.00 \\
1.24 \\
1.24 \\
1.68 \\
2.53 \\
1.41\end{array}$ & $\begin{array}{l}0.64-2.42 \\
0.64-2.42 \\
0.34-5.28 \\
0.71-6.05 \\
0.39-5.05\end{array}$ & $\begin{array}{l}\text { Age, hypertension, diabe- } \\
\text { tes, BMI, high cholesterol, } \\
\text { oral contraceptive use, } \\
\text { HRT, age of smoking } \\
\text { commencement, and fol- } \\
\text { low-up period. }\end{array}$ & \\
\hline $\begin{array}{l}\text { Kurth et al. [19] } \\
\text { US Physicians' } \\
\text { Health Study, } \\
2003\end{array}$ & $\begin{array}{c}108 \\
(22022 \\
\text { Males) }\end{array}$ & $\begin{array}{l}\text { Rest of } \\
\text { Cohort }\end{array}$ & $\begin{array}{l}\text { Never Smokers } \\
\text { Past Smokers } \\
\text { Current } \\
(<20 / \text { day }) \\
\text { Current }(\geq \\
\text { 20/day) }\end{array}$ & $\begin{array}{l}1.00 \\
0.80 \\
1.60 \\
2.06\end{array}$ & $\begin{array}{l}0.54-1.20 \\
0.50-5.07 \\
1.08-3.96\end{array}$ & $\begin{array}{l}\text { Age, exercise, parental } \\
\text { history of MI before age } \\
60 \text {, alcohol consump- } \\
\text { tion, and randomized } \\
\text { treatment group }\end{array}$ & \\
\hline
\end{tabular}

ICH, intracerebral haemorrhage; RR, relative risk; OR, odds ratio; 95\% CI, 95\% Confidence Interval; †adjustments, refers to adjustments made for either univariate or multivariate analysis. TIA, transient ischaemic attack; MI, myocardial infarction; BMI, body mass index; HRT, hormone replacement therapy. 
smoke than in the mainstream smoke inhaled by the smoker [42]. As many investigations have been made into the role of active smoking in the development of stroke, it is interesting to find that only a small number of studies have been focused on the role of ETS in the pathogenesis of stroke.

The first examination of the link between exposure to ETS and the development of stroke was conducted by Lee and colleagues using a hospital based case-control study [43]. The study included nonsmokers whose spouses were current smokers with lung cancer. The non-smoking spouses $(n=55)$ were then matched to controls with non-smoking spouses $(\mathrm{n}=254)$. No significant increase in the risk of stroke was found among smokers' spouses (RR $0.90,95 \% \mathrm{CI}$, 0.53-1.52) when compared to non-smokers' spouses. In contrast to these findings, in a case-control study involving 452 cases, You and colleagues reported a borderline association between ischaemic stroke and exposure to ETS via a spouse in non-smokers (OR 1.70, 95\% CI, 0.98-2.92) [33].

The most recent study on passive smoking and stroke was a population based case-control study conducted in New Zealand [8]. The study involved 521 cases of first ever stroke and 1,800 community-based controls. The authors defined passive smokers as those exposed to smoking via a household member who regularly smoked in their presence or a co-worker who smoked indoors in their presence for more than one of the past 10 years. After adjusting for potentially confounding factors such as sex, hypertension and diabetes, the odds ratio of developing stroke associated with exposure to ETS was 1.82 (95\% CI, 1.34-2.49). This provides some evidence that non-smokers who are exposed to ETS have a greater risk of developing stroke than those not exposed to ETS.

In support of these findings, potential mechanisms whereby ETS may contribute to the pathogenesis of stroke have been identified. The Atherosclerosis Risk in Communities (ARIC) study investigators presented findings linking ETS to the development of carotid atherosclerosis [44]. After controlling for demographic, life-style and other risk factors, intimal-medial thickening was found to be greater in non-smokers who were exposed to ETS, than non-smokers who were not exposed to ETS. In addition, the rate of progression of intimal-medial thickening was significantly greater among non-smokers exposed to ETS $(\mathrm{p}=0.003)$. Furthermore, Kiechl and colleagues found non-smokers exposed to ETS had a greater risk of developing early (OR 1.3, 95\% CI, 1.0-1.8) and advanced atherosclerosis
(OR 1.5, 95\% CI, 1.0-2.2) than non-smokers not exposed to ETS [45].

Overall, data from the few studies conducted on exposure to ETS and the development of stroke, together with data concerning ETS and atherosclerosis, provide some support for the notion that ETS can lead to the development of stroke. To clarify the role of ETS in the development of stroke, studies must be designed to determine whether altering the amount or duration of ETS changes the rate of stroke within a population. More evidence is needed on the role of ETS in the development of stroke. An examination of the effect of ETS by stroke subtype may better evaluate the relationship between this potentially modifiable risk factor and stroke.

\section{CIGARETTE SMOKING IN THE PATHOGENESIS OF STROKE}

Smoking appears to be involved in the pathogenesis of stroke via two mechanisms. First, smoking can cause direct damage to the vasculature, altering both its architecture and function [44-54]. Second, smoking has effects on haemodynamic factors within the circulation [53, 55-64]. By discussing the implications of these alterations in function by stroke aetiology, the role of smoking in the pathogenesis of stroke is better elucidated. Two distinct types of stroke will be discussed, cerebral infarction and haemorrhagic stroke (including ICH and $\mathrm{SAH}$ ).

\section{Smoking and the development of cerebral infarction}

Cerebral infarction occurs due to a disruption of the blood supply to the cerebral arteries. This can be a consequence of either occlusion of the cerebral vessels themselves or due to occlusion of the carotid arteries. There are a number of ways in which this occlusion can occur including artery occlusion by atherosclerosis and its associated plaques and thrombi or via emboli from a ruptured atherosclerotic plaque.

Smoking is a major factor in the development of atherosclerosis. In the ARIC study current smokers were found to have the greatest progression of atherosclerosis over time, at a rate $50 \%$ greater than in nonsmokers [44]. Furthermore, it was found that ETS exposure was associated with an approximately 20\% greater rate of atherosclerosis progression than for nonsmokers not exposed to ETS. Similar findings have been reported by others [48].

Smoking is believed to induce the development of atherosclerosis by initiating endothelial injury, presum- 
ably due to either the production of oxygen radicals or via direct toxic effects of cigarette smoke constituents. Even brief exposure to cigarette smoke has been found to activate leukocytes, stimulating the release of the pro-coagulant, von Willebrand Factor (vWF) and causing endothelial damage [56]. This initiates a cascade of inflammatory mechanisms that result in atherosclerosis.

The mechanisms by which endothelial dysfunction and a reduction in dilatory ability occur were further investigated by Fang and colleagues in the cerebral arteries of rats [49]. They reported that nicotine infusion reduced the dilatory ability of pial vessels to nitric oxide synthase (NOS) dependant agonists. In addition, this response was inhibited by administration of superoxide dismutase. These findings provide evidence that nicotine has its effects via the formation of oxygen radicals. The authors speculated that this oxygen radical induced impairment of dilation is important in the occurrence of vascular dysfunction after exposure to cigarette smoke.

Studies on arteries of human smokers have found similar results to Fang and colleagues. Poredôs and colleagues reported data on the intima-media thickness (IMT) of smokers compared with non-smokers, with IMT being used as a measure of atherosclerotic change [65]. The investigators found that those who smoked had a significantly greater IMT than non-smokers. In addition, Celermajer and colleagues demonstrated that the arteries of smokers had diminished or absent flowmediated dilation, giving evidence of endothelial dysfunction [66].

The ramifications of the reduction in dilatory ability following smoking may place smoking individuals at a higher risk of cerebral ischaemic events in two ways. First, due to both a reduced ability to respond to alteration in perfusion pressure, and second, due to lack of distensibility of the arterial wall as a result of endothelial dysfunction. The notion that this lack of distensibility of the arterial wall may increase the risk of atherosclerotic plaque rupture, leading to emboli and subsequent infarction, was presented by Kool and colleagues [52]. They found that blood pressure and heart rate were significantly increased following smoking, whereas carotid artery distensibility was significantly decreased. It was postulated that the increased wall stiffness, blood pressure and heart rate could cause an increase in load on the vessel wall, which could lead to plaque rupture and acute ischaemic events. This is particularly relevant in light of evidence that smokers have increased levels of atherosclerosis.

Studies conducted on the reactivity of the cerebral vessels of smokers are particularly pertinent to the role of smoking in the development of stroke. Terborg and colleagues investigated the reactivity of the cerebral circulation in smokers to hypercapnia using nearinfrared spectroscopy and transcranial Doppler sonography [67]. It was found that at rest smokers have normal autoregulatory ability, yet immediately after smoking their vasomotor reactivity to hypercapnia was impaired. This was due to a reduced vasodilatory ability reflecting endothelial dysfunction. It was suggested that these acute reversible effects of cigarette smoking could place smokers at an enhanced stroke risk, presumably due to the reduced ability of the cerebral circulation to response to decreases or disruptions in perfusion pressure in this period immediately following smoking.

In addition to the atherosclerotic changes that cigarette smoking induces in the vessel wall, smoking also has detrimental effects on the coagulant/anticoagulant balance throughout the vascular system of smokers. This imbalance predisposes these individuals to thrombosis and therefore an increased risk of cerebral infarction. Hioki and colleagues investigated the effects of smoking on thrombin generation, which is important in the conversion of fibrinogen to fibrin in the coagulant cascade [57]. It was evident from their findings that even when not smoking, current smokers had significantly elevated levels of thrombin. These levels were seen to increase further immediately after smoking. Examination of serum of smokers also reveals that smokers have significantly increased fibrinogen and white blood cell counts when compared to nonsmokers [68], giving further credence to the suggestion that smokers are more prone to coagulation and thrombosis than non-smokers. Investigations on the effect of nicotine on haemostatic functions have found that nicotine increases the production of the tissue plasminogen activator (tPA) inhibitor (plasminogen activator inhibitor-1, PAI-1). The presence of tPA in the circulation is important for fibrinolysis. Its inhibition is regulated by PAI-1 from both platelet and endothelial sources, which binds to fibrin strands causing the inactivation of tPA. This ultimately results in a reduction in fibrinolysis and therefore thrombus formation. A study exposing human brain endothelial cells to nicotine is particularly relevant to the discussion of smoking and stroke. In this study Zidovetski and colleagues discovered that the administration of nicotine to these cells resulted in an increased production of PAI-1 [63].

Human studies show similar findings, with longterm smokers shown to have significantly increased levels of PAI-1 when compared to non-smokers [61]. In 
addition, the ratio of tPA to PAI-1 was found to be lowest in smokers, suggesting that smokers have the lowest potential for fibrinolytic activity that may lead to a greater tendency for thrombus among smokers. The authors noted the apparent close association between tPA and PAI-1 levels and suggested that there is most probably mechanisms ensuring a balance of the activator and inhibitor. In smokers it would appear that this balance is not maintained and this may predispose these individuals to pathological conditions such as stroke. Investigations into tPA and PAI-1 levels in stroke patients reveal that patients have significantly elevated plasma levels of both tPA and PAI-1, along with increased active PAI-1 [64]. It was also found that there was a significant increase in tPA: PAI-1 complexes, suggesting that PAI-1 is inhibiting active tPA. This provides evidence that patients with stroke may indeed have decreased fibrinolytic activity resulting in an increased risk of thrombosis and therefore cerebral infarction.

These investigations demonstrate that cigarette smoking induces both short-term and long-term alterations in haemodynamic variables, and can also alter arterial wall architecture resulting in atherosclerosis. In turn these alterations can result in occlusion of vessels due to stenosis within the carotid region and emboli from a ruptured atherosclerotic plaque, increasing the risk of a cerebral infarction. The reduction in the risk of cerebral infarction following smoking cessation may be due to the resolution of acute pathological changes caused by smoking such as alterations in haemodynamics, rather than a reversal of more chronic changes such as atherosclerosis. However, this is speculative as the effects of smoking cessation on these variables has not been investigated.

\section{Smoking and the development of haemorrhagic stroke}

The role of smoking in the pathogenesis of haemorrhagic stroke has been less investigated. This is surprising given the strong association found between smoking and SAH in particular $[6,12,16,18,19,26,28]$. Cerebral haemorrhage occurs due to a rupture of a cerebral artery causing an influx of blood into either the subarachnoid space (in SAH) or into the brain parenchyma (in ICH).

$\mathrm{SAH}$ is known to be due to the rupture of an artery and in many cases the rupture of a saccular aneurysm [69]. Importantly, it has been found that smokers have a greater amount of aneurysms that are also larger in size than those in non-smokers $[70,71]$. ICH is gen- erally associated with the rupture of small arteries within the brain parenchyma. As with cerebral infarction, it would appear that it is structural damage to the arterial wall that leads to the increased risk of haemorrhage. Aneurysms and/or rupture of cerebral arteries occur due to a weakening of the vessel wall. In the case of aneurysm it has been proposed that the degradation of elastin within the blood vessel wall may weaken the wall, making it susceptible to dilatation at points of high flow disturbance such as the branching of arteries within the Circle of Willis [70]. This degradation of elastin may be due to a reduction of the activity of protease inhibitors, namely $\alpha_{1}$ antitrypsin. Smoking is known to inactivate $\alpha_{1}$ antitrypsin via peroxynitrates and $\bullet \mathrm{OH}$ compounds found within cigarette smoke [50]. Furthermore, examination of smokers has found increased elastase degradation products in their urine [72]. Tartara and colleagues suggested that a defect in $\alpha_{1}$ antitrypsin activity may cause an imbalance between proteolytic enzymes and systemic inhibitory capacity; in turn there would be an increase in collagen turnover resulting in a weakening of the arterial wall [73]. This might result in the progression of an aneurysm or also rupture of aneurysm, resulting in $\mathrm{SAH}$, or the decreased strength of vessel walls could result in intracerebral arterial rupture resulting in ICH. In support of this hypothesis are data showing that smoking patients with SAH have significantly reduced levels of $\alpha_{1}$ antitrypsin [73].

The potential implications of these structural alterations in the arterial wall of smokers may also lead to an increased risk of haemorrhage due to the alteration in blood pressure caused by smoking. A sharp rise in blood pressure has been observed immediately after smoking and can last for up to three hours [22,52]. Juvela and colleagues proposed that these rises in blood pressure could contribute to the rupture of aneurysms or even small intracerebral arteries [74].

The data relating to acute changes due to smoking, such as blood pressure surges, teamed with data on chronic smoking related changes, such as arterial wall degradation, provide a hypothesis for the role of smoking in the development of haemorrhagic stroke. Furthermore, it is evident that the cessation of smoking may lower haemorrhagic stroke risk due to the elimination of acute effects such as blood pressure surges. However, the chronic effects of smoking such as arterial wall degradation may remain. This may explain why although the risk of haemorrhagic stroke declines with smoking cessation, it does not revert to that of an individual who has never smoked $[16,18,19,26]$. 


\section{CONCLUSION}

Smoking is an established risk factor for both cerebral ischaemia and subarachnoid haemorrhage. However, its role in ICH is less clear. There is supporting evidence for a causal relationship between smoking and $\mathrm{CI}$ or SAH. This is supported by reports of a doseresponse relationship between smoking levels and these two types of stroke, as well as a return to never smoking risk levels with increased time since quitting smoking. Furthermore, the biological plausibility of these findings provides further evidence for the role of smoking in these diseases.

Establishing smoking as a significant risk factor for $\mathrm{CI}$ and $\mathrm{SAH}$ is important, as this is a modifiable risk factor. The evidence that among smokers who cease smoking the risk of both of these forms of stroke returns to never smoking levels over time indicates that people who cease smoking can benefit in an important way. Prevention still remains the most effective way of reducing the impact of stroke.

Acknowledgement: This work was supported by grants from the National Health \& Medical Research Council (NHMRC), the Victorian Health Promotion Foundation, the Foundation for High Blood Pressure Research and the National Stroke Foundation.

\section{REFERENCES}

1. Hughson W, Mann J, Garrod A. Intermittent claudication prevalence and risk factors. British Medical Journal 1978; 1: 1379-1381.

2. Gordon, T, Kannel WB. Predisposition to atherosclerosis in the head, heart and legs: the Framingham Study. Journal of the American Medical Association 1972; 221: 661-666.

3. Aldoori MI Rahman SH. Smoking and stroke: a causative role. Heavy smokers with hypertension benefit most from stopping. British Medical Journal 1998; 317: 762-3.

4. Bell BA, Ambrose J. Smoking and the risk of stroke. Acta Neurochirurgica 1982; 64: 1-7.

5. Berger K, Schulte H, Stogbauer F, Assmann G. Incidence and risk factors for stroke in an occupational cohort: the PROCAM study. Stroke 1998; 29: 1562-1566.

6. Bonita R. Cigarette smoking, hypertension and the risk of subarachnoid hemorrhage: a populationbased case-control study. Stroke 1986; 17: 831-835.

7. Bonita R, Scragg R, Stewart A, Jackson RT, Beaglehole R. Cigarette smoking and the risk of pre- mature stroke in men and women. British Medical Journal 1986; 293: 6-8.

8. Bonita R, Duncan J, Truelsen T, Jackson RT, Beaglehole R. Passive smoking as well as active smoking increases the risk of acute stroke. Tobacco Control 1999; 8: 156-160.

9. Colditz GA, Bonita R, Stampfer MJ, Willett WC, Rosner B, Speizer FE, Hennekens CH. Cigarette smoking and risk of stroke in middle-aged women. New England Journal of Medicine 1988; 318: 937-41.

10. Donnan GA, McNeil JJ, Adena MA, Doyle AE, O'Malley HM, Neill GC. Smoking as a risk factor for cerebral ischaemia. Lancet 1989; 2: 643-647.

11. Feigin VL, Wiebers DO, Nikitin YP, O'Fallon WM, Whisnant JP. Risk factors for ischemic stroke in a Russian community: a populationbased case-control study. Stroke 1998; 29: 34-39.

12. Gill JS, Shipley MJ, Tsementzis SA, Hornby R, Gill SK, Hitchcock ER, Beevers DG. Cigarette smoking: a risk factor for hemorrhagic and nonhemorrhagic stroke. Archives of Internal Medicine 1989; 149: 2053-2057.

13. Gorelick, PB, Rodin MB, Langenberg P, Hier DB, Costigan J. Weekly alcohol consumption, cigarette smoking, and the risk of ischemic stroke: results of a case-control study at three urban medical centers in Chicago, Illinois. Neurology 1989; 39: 339343.

14. Grau AJ, Weimar C, Buggle F, Heinrich A, Goertler M, Neumaier S, Glahn J, Brandt T, Hacke W, Diener H-C. Risk factors, outcome and treatment in subtypes of ischemic stroke: the German Stroke Data Bank. Stroke 2001; 32: 2559-2566.

15. Haheim LL, Holme I, Hjermann I, Leren P. Smoking habits and risk of fatal stroke: 18 years followup of the Oslo study. Journal of Epidemiology and Community Health 1996; 50: 621-624.

16. Isaksen J, Egge A, Waterloo K, Romner B, Ingebrigtsen $\mathrm{T}$. Risk factors for aneurysmal subarachnoid haemorrhage: the Tromsø study. Journal of Neurology Neurosurgery and Psychiatry 2002; 73: 185-187.

17. Jamrozik K, Broadhurst RJ, Anderson CS, Stewart-Wynne EG. The role of lifestyle factors in the etiology of stroke: a population-based case-control study in Perth, Western Australia. Stroke 1994; 25: 51-59.

18. Kawachi I, Colditz GA, Stampfer MJ, Willett WC, Manson JE, Rosner B, Speizer FE, Hennekens $\mathrm{CH}$. Smoking cessation and decreased risk of 
stroke in women. Journal of the American Medical Association 1993; 269: 232-236.

19. Kurth T, Kase CS, Berger K, Schaeffner ES, Buring JE, Gaziano M. Smoking and the risk of hemorrhagic stroke in men. Stroke 2003; 34: 11511155.

20. Lidegaard, Ø. Oral contraception and risk of a cerebral thromboembolic attack: results of a casecontrol study. British Medical Journal 1993; 306: 956-963.

21. Lee T-K, Huang Z-S, Ng S-K, Chan K-WA, Wang Y-S, Liu H-W, Lee J-J. Impact of alcohol consumption and cigarette smoking on stroke among the elderly in Taiwan. Stroke 1995; 26: 790-794.

22. Longstreth W, Nelson L, Koepsell T, van Belle G. Cigarette smoking, alcohol use and subarachnoid haemorrhage. Stroke 1992; 23: 1242-1249.

23. Love BB, Biller J, Jones MP, Adams HP, Bruno A. Cigarette smoking: a risk factor for cerebral infarction in young adults. Archives of Neurology 1990; 47: 693-698.

24. Monforte R, Estruch R, Graus F, Nicolas JM, Urbano-Marquez A. High ethanol consumption as risk factor for intracerebral hemorrhage in young and middle-aged people. Stroke 1990; 21: 15291532.

25. Petitti DB, Sidney S, Burnstein A, Wolf S, Quesenberry C, Ziel HK. Stroke in users of low-dose oral contraceptives. New England Journal of Medicine 1996; 335: 8-15.

26. Qureshi AI, Suri MFK, Yahia AM, Suarez JI, Guterman LR, Hopkins LN, Tamargo REJ. Risk factors for subarachnoid hemorrhage. Neurosurgery 2001; 49: 607-612.

27. Rodriguez BL, D'Agostino TB, Abbot RD, Kagan A, Burchfiel AM, Yano K, Ross GW, Silbershatz H, Higgins MW, Popper J, Wolf PA, Curb JD. Risk of hospitalized stroke in men enrolled in the Honolulu heart program and the Framingham study: a comparison of incidence and risk factor effects. Stroke 2002; 33: 230-237.

28. Shinton R, Beevers G. Meta-analysis of relation between cigarette smoking and stroke. British Medical Journal 1989; 298: 789-794.

29. Wannamethee SG, Shaper AG, Whincup PH, Walker M. Smoking cessation and the risk of stroke in middle-aged men. Journal of the American Medical Association 1995; 274: 155-160.

30. Weir BKA, Kongable GL, Kassell NF, Schultz JR, Truskowski LL, Sigrest S. Cigarette smoking as a cause of aneurysmal subarachnoid haemorrhage and risk of vasospasm: a report of the Cooperative Aneurysm Study. Journal of Neurosurgery 1998; 89: 405-411.

31. Wolf PA, D'Agostino TB, Kannel WB, Bonita R, Belanger AJ. Cigarette smoking as a risk factor for stroke. Journal of the American Medical Association 1988; 259: 1025-1029.

32. You R, McNeil JJ, Hurley SF, Farish SJ, O'Malley HM, Quang L, Donnan GA. Smoking as a risk factor for cortical ischaemia presumably due to carotid occlusive disease. Neuroepidemiology 1993; 12: 141-147.

33. You R, Thrift AG, McNeil JJ, Davis SM, Donnan GA. Ischemic stroke risk and passive exposure to spouses' cigarette smoking. American Journal of Public Health 1999; 89: 572-575.

34. Thrift AG, Dewey HM, Macdonell RAL, McNeil JJ, Donnan GA. Incidence of the major stroke subtypes. Initial findings from the North East Melbourne Stroke Incidence Study (NEMESIS). Stroke 2001; 32: 1732-1738.

35. Ellekjær EF, Wyller TB, Sverre JM, Holmen J. Lifestyle factors and risk of cerebral infarction. Stroke 1992; 23: 829-834.

36. Benfante R, Yano K, Hwang L-J, Curb JD, Kagan A, Ross W. Elevated serum cholesterol is a risk factor for both coronary heart disease and thromboembolic stroke in Hawaiian Japanese men: implications of shared risk. Stroke 1994; 25: 814820.

37. Sudlow CLM, Warlow CP. Comparable studies of the incidence of stroke and its pathological types: results from an international collaboration. Stroke 1997; 28: 491-499.

38. Hackett ML, Duncan JR, Anderson CS, Broad JB, Bonita R. Health-related quality of life among long-term survivors of stroke: results from the Auckland stroke study, 1991-1992. Stroke 2000; 31: 440-7.

39. Thrift AG, McNeil JJ, Donnan GA. The risk of intracerebral haemorrhage with smoking. Cerebrovascular Diseases 1999; 9: 34-39.

40. Woo D, Sauerbeck LR, Kissela BM, Khoury JC, Szaflarski JP, Gebel J, Shukla R, Pancioli AM, Jauch EC, Menon AG, Deka R, Carrozzella JA, Moomaw CJ, Fontaine RN, Broderick JP. Genetic and environmental risk factors for intracerebral hemorrhage: preliminary results of a populationbased study. Stroke 2002; 33: 1190-1196.

41. Ariesen MJ, Claus SP, Rinkel GJE, Algra A. Risk factors for intracerebral hemorrhage in the general 
population, a systematic review. Stroke 2003; 34 : 2065-2066.

42. U.S. Environmental Protection Agency. Respiratory Health Effects of Passive Smoking: Lung Cancer and Other Disorders. Washington DC: Office of Research and Development, 1992.

43. Lee PN, Chamberlain J, Alderson MR. Relationship of passive smoking to risk of lung cancer and other smoking-associated diseases. British Journal of Cancer 1986; 54: 97-105.

44. Howard G, Wagenknecht LE, Burke GL, DiezRoux A, Evans GW, McGovern P, Nieto J, Tell GS. Cigarette smoking and progression of atherosclerosis - The atherosclerosis risk in communities (ARIC) study. Journal of the American Medical Association 1998; 279: 119-124.

45. Kiechl S, Werner P, Egger G, Oberhollenzer F, Mayr M, Xu Q, Poewe W, Willeit J. Active and passive smoking, chronic infections, and the risk of carotid athersclerosis: prospective results from the Bruneck Study. Stroke 2002; 33: 2170-2176.

46. Conklin BS, Zhao W, Zhong D-S, Chen C. Nicotine and cotinine up-regulate vascular endothelial growth factor expression in endothelial cells. American Journal of Pathology 2002; 160: 413418.

47. Diezroux AV, Nieto FJ, Comstock GW, Howard G, Szklo M. The relationship of active and passive smoking to carotid atherosclerosis 12-14 years later. Preventive Medicine 1995; 24: 48-55.

48. Djousse L, Myers RH, Province MA, Hunt SC, Eckfeldt JH, Evans G, Peacock JM, Ellison RC. Influence of apolipoprotein E, smoking, and alcohol intake on carotid athersclerosis: National Heart, Lung, and Blood Institute Family Heart Study. Stroke 2002; 33: 1357-1361.

49. Fang Q, Sun H, Mayhan WG. Impairment of nitric oxide synthase-dependent dilatation of cerebral arterioles during infusion of nicotine. American Journal of Physiology - Heart and Circulatory Physiology 2003; 284: H528-534.

50. Evans MD, Pryor WA. Cigarette smoking, emphysema and damage to al proteinase inhibitor. American Journal of Physiology 1994; 266: L593L611.

51. Gairola CG, Drawdy ML, Block AE, Daugherty A. Sidestream cigarette smoke accelerates atherogenesis in apolipoprotein E-/- mice. Atherosclerosis 2001; 156: 49-55.

52. Kool MJ, Hoeks AP, Struijker Boudier HA, Reneman RS, Van Bortel, LM. Short- and long-term effects of smoking on arterial wall properties in habitual smokers. Journal of the American College of Cardiology 1993; 22: 1881-1886.

53. Lassila, R, Seyberth H, Haapanen A, Scweer H, Koskenvuo M, Laustiola K. Vasoactive and atherogenic effects of cigarette smoking: a study of monozygotic twins discordant for smoking. British Medical Journal 1988; 297: 955-957.

54. Mast H, Thompson JLP, Lin I-F, Hofmeister C, Hartmann A, Marx P, Mohr JP, Sacco RL. Cigarette smoking as a determinant of high-grade carotid artery stenosis in Hispanic, Black and White patients with stroke or transient ischemic attack. Stroke 1998; 29: 908-912.

55. Padro T, Emeis JJ, Steins M, Schmid KW, Kienast J. Quantification of plasminogen activators and their inhibitors in the aortic vessel wall in relation to the presence and severity of atherosclerotic disease. Arteriosclerosis, Thrombosis, and Vascular Biology 1995; 15: 893-902.

56. Blann AD, Kirkpatrick U, Devine C, Naser S, McCollum CN. The influence of acute smoking on leucocytes, platelets and the endothelium. Atherosclerosis 1998; 141: 133-139.

57. Hioki Y, Aoki N, Kawano K, Homori M, Hasumura Y, Yasumura T, Maki A, Yoshino H, Yanagisawa A, Ishikawa K. Acute effects of cigarette smoking on platelet-dependant thrombin generation. European Heart Journal 2001; 22: 56-61.

58. Iso H, Shimamoto T, Sato S, Koike K, Ida M, Komachi Y. Passive smoking and plasma fibrinogen concentrations. American Journal of Epidemiology 1996; 144: 1151-4.

59. Khrenov AV, Ananyeva NM, Griffin JH, Saenko EL. Coagulation pathways in atherothrombosis. Trends in Cardiovascular Medicine 2002; 12: 317324.

60. Nowak J, Andersson K, Benthin G, Chen J, Karlberg K-E, Sylven C. Effect of nicotine infusion in humans on platelet aggregation and urinary excretion of a major thromboxane metabolite. Acta Physiologica Scandinavica 1996; 157: 101-107.

61. Simpson AJ, Gray RS, Moore NR, Booth NA. The effects of chronic smoking on the fibrinolytic potential of plasma and platelets. British Journal of Haematology 1997; 97: 208-213.

62. Zhu BQ, Parmley WW. Hemodynamic and vascular effects of active and passive smoking. American Heart Journal 1995; 130: 1270-1275.

63. Zidovetzki R, Chen P, Fisher M, Hofman F. Nicotine increases plasminogen activator inhibitor-1 
production by human brain endothelial cells via protein kinase C-associated pathway. Stroke 1999; 30: 651-655.

64. Zunker P, Schick A, Padro T, Kienast J, Phillips A, Ringelstein EB. Tissue plasminogen activator and plasminogen activator inhibitor in patients with acute ischemic stroke: relation to stroke etiology. Neurological Research 1999; 21: 727-732.

65. Poredos P, Orehek M, Tratnik E. Smoking is associated with dose-related increase of intima-media thickness and endothelial dysfunction. Angiology 1999; 50: 201-8.

66. Celermajer D, Keld S, Georgakopoulos D, Bull C, Thomas O, Robinson J, Deanfield J. Cigarette smoking is associated with dose-related and potentially reversible impairment of endotheliumdependent dilation in healthy young adults. Circulation 1993; 88: 2149-2155.

67. Terborg C, Bramer S, Weiller C, Rother J. Shortterm effect of cigarette smoking in $\mathrm{CO} 2$-induced vasomotor reactivity in man: A study with nearinfrared spectroscopy and transcranial Doppler sonography. Journal of the Neurological Sciences 2002; 205: 15-20.

68. Magyar M, Szikszai Z, Balla J, Valikovics A, Kappelmayer J, Imre S, Balla G, Jeney V, Csiba L, Bereczki D. Early onset carotid atherosclerosis is associated with increased intima-media thickness and elevated serum levels of inflammatory markers. Stroke 2003; 34: 56-63.

69. Zhang B, Fugleholm K, Day LB, Ye S, Weller RO, Day IN. Molecular pathogenesis of subarachnoid haemorrhage. International Journal of Biochemistry and Cell Biology 2003; 35: 1341-1360.

70. Qureshi AI, Suarez JI, Parekh PD, Sung GY, Geocadin R, Bhardwaj A, Tamargo REJ, Ulatowski JA. Risk Factors for Multiple Intracranial Aneurysms. Neurosurgery 1998; 43: 22-26.

71. Qureshi AI, Sung GY, Fareed SM, Straw RN, Guterman LR, Hopkins LN. Factors associated with aneurysm size in patients with subarachnoid haemorrhage: effect of smoking and aneurysm location. Neurosurgery 2000; 46: 44-50.

72. Stone P, Gottlieb D, O'Connor G, Ciccolella D, Breuer R, Bryan-Rhadfi J, Shaw H, Franzblau C, Snider G. Elastin and collagen degradation products in urine of smokers with and without chronic obstructive pulmonary disease. American Journal of Respiratory and Critical Care Medicine 1995; 151: 952-959.

73. Tartara F, Gaetani P, Tancioni F, Guagliano A, Klersy C, Forlino A, Marzatico F, Rodriguez y Baena R. Alpha1-antitrypsin activity in subarachnoid hemorrhage. Life Sciences 1996; 59: 15-20.

74. Juvela S. Prevalence of risk factors in spontaneous intracerebral hemorrhage and aneurysmal subarachnoid hemorrhage. Archives of Neurology 1996; 53: 734-740. 